\title{
A Study on Relationship between Soil and P Adsorption Parameters
}

\author{
Lalit Kumar Yadav, Rakesh Kumar Bhagat and Gourav Kumar Jatav* \\ Soil Science and Agricultural Chemistry, Indira Gandhi Krishi Vishwavidhyalaya, \\ Raipur-492012, Chhattisgarh, India \\ *Corresponding author
}

\begin{tabular}{|c|c|}
\hline & A B S T R A C T \\
\hline & \multirow{7}{*}{$\begin{array}{l}\mathrm{P} \text { adsorption maximum was significantly and positively correlated with } \mathrm{pH}(\mathrm{r}= \\
\left.0.85^{* *}\right) \text {, clay }\left(\mathrm{r}=0.96^{* *}\right) \text { and silt }+ \text { clay }\left(\mathrm{r}=0.94^{* *}\right) \text {, however, the binding } \\
\text { energy showed a significant and positive correlationship with organic carbon ( } \mathrm{r}= \\
\left.0.68^{*}\right) \text { only. In case of Freundlich Isotherm there was no significant relationship } \\
\text { between Freundlich adsorption parameters and soil properties except between the } \\
\text { empirical constant ' } \mathrm{K} \text { ' and soil } \mathrm{pH} \text {. Clay content dominated the P adsorption of } \\
\text { these soils as indicated by its significant regression coefficient. Soil } \mathrm{pH} \text {, organic } \\
\text { carbon, clay, clay + silt, available } \mathrm{P} \text { and total P together accounted for } 98 \% \text { of } \\
\text { Langmuir 'b', 52\% of Langmuir ' } \mathrm{K} \text { ', and } 78 \% \text { of Freundlich ' } \mathrm{n} \text { ' and } 56 \% \text { of } \\
\text { Freundlich ' } \mathrm{K} \text { ' respectively. The values of buffering capacity for Vertisol, Alfisol } \\
\text { and Inceptisol were } 1.90,0.86 \text { and } 0.22 \text { and the P sorption at } 0.2 \mathrm{ppm} \text { solution } \\
\text { concentration was found to be } 61.40,49.27 \text { and } 30.19 \text { for Vertisol, Alfisol and } \\
\text { Inceptisol respectively. }\end{array}$} \\
\hline Keywords & \\
\hline & \\
\hline $\begin{array}{l}\mathrm{C} \\
\mathrm{P} \\
\mathrm{p}\end{array}$ & \\
\hline At & \\
\hline $\begin{array}{l}\text { Accepted: } \\
\text { 26 June } 2017 \\
\text { Available Online: } \\
\text { 10 August } 2017\end{array}$ & \\
\hline & \\
\hline
\end{tabular}

\section{Introduction}

It is now well establish that adsorption parameter can utilized as an index for predicting the availability of phosphorus to crops (Vig et al., 1978a; Singh and Sarkar, 1985). The magnitude and rate of $\mathrm{P}$ sorption mainly depend upon the properties of soils and phosphate sources. Soils differ widely in their chemical and physical makeup according to geological and geographical location.

Organic matter, clay (Jalali and Sharma 1987) and hydrous oxides of $\mathrm{Fe}$ and $\mathrm{Al}$ (Tekchand and Tomar 1993) in acid soils and calcite and $\mathrm{Ca}^{2+}$ (Holford et al., 1990) in calcareous soils, play a major role in phosphate sorption. Various other factors that affect the amount of phosphate retained by the soil through adsorption process are $\mathrm{pH}$ (Tekchand and
Tomar, 1995), temperature and time of contact of phosphorus with the soil.

Soil $\mathrm{pH}$ is a critical factor in phosphate sorption $\mathrm{P}$ usually decreases with increases in soil $\mathrm{pH}$. It has been suggested that organic matter increase the availability of $\mathrm{P}$ by chelating the $\mathrm{P}$ fixing cations and $\left(\mathrm{Al}^{3+}, \mathrm{Fe}^{3+}\right.$, $\mathrm{Ca}^{2+}$ ), exchange of adsorbed $\mathrm{PO}_{4}{ }^{3-}$ by organic anions, protective action and decrease in $\mathrm{pH}$ and Eh of the soils (Stevenson, 1982; khanna et al., 1984).

Addition of different $\mathrm{P}$ fertilizers of varying solubilities along with organic manure in soil retained higher amounts of saloid $\mathrm{P}$ and available $\mathrm{P}$ for longer period due to their reduced fixation as calcium phosphate 
(Tomar. 200). The clay fraction, $\mathrm{P}$ dominantly containing kaolinite and accessory oxides and hydrous oxides are of $\mathrm{Fe}$ and $\mathrm{Al}$, played an active role in $\mathrm{P}$ sorption. Hydrous oxide of $\mathrm{Fe}$ and $\mathrm{Al}$ has been found to occur as fine coatings on surface of clay minerals in soil, these coating characterized by large surfaces area, hold an appreciable quantity of phosphate, there by implying a secondary role of crystalline aluminosilicate in phosphate sorption (Ryden and Pratt, 1975b).

\section{Materials and Methods}

Bulk soil samples from $0-15 \mathrm{~cm}$ were collected four soil soil samples each from different sites belonging to three soil orders Inceptisol, Alfisol and Vertisol were collected from the experimental farm so as to have large variation in their properties and analyzed for different soil properties by following different standard procedure.

The Inceptisols are fine, mixed, hyperthermic, udic ustochrept and shallow in depth, yellow in colour having small quantities of $\mathrm{CaCO}_{3}$, and iron concretion which increases with depth. They are locally known as "Matasi". These soil drain much more rapidly than Vertisols and are leached to a greater extent. The Vertisols are fine montmorillonite, hyperthermic, udic chromustert, locally called as Kanhar and identified as Arang \| series. They are usually deep, heavy and clayey (50$55 \%)$. Dark brown to black in colour and neutral to alkaline in reaction due to presence of lime concretions. The Alfisol are classified as fine, loamy, mixed hyperthermic, udic Rhodustalfs, udic haplustalfs. Haplustalfs is locally known as "Dorsa"' and have line and numerous iron concretions. The soils have moderate depth and are brownish grey in colour.

The $\mathrm{pH}$ was measured with $\mathrm{pH}$ meter using 1:2.5 soil water suspensions (piper, 1967).
The clear suspension extract obtained from $\mathrm{pH}$ was also utilized for EC measurement using conductivity bridge (Black, 1965). Organic carbon was determind by Walkley and Black's rapid titration method as determind by Black (1965). Soil texture was determined by International Pipette Method as described by Piper (1967). Available P was determined by Olsen method using $0.5 \mathrm{M}$ sodium bicarbonate $(\mathrm{pH} 8.5)$ as an extractant using charcoal free from soluble phosphorus was used to absorb the dispersed organic matter and make the filtrate colourless for further colorimetric analysis (Jackson, 1978). Total Phosphorus was determined by using $\mathrm{HCIO}_{4}-60 \%$ solution as suggested by Olsen and Sommers, (1982).

\section{Results and Discussion}

The $\mathrm{P}$ adsorption study was conducted on three soils namely Inceptisol, Alfisol and Vertisol. The characteristics physico-chemical properties of these soils are presented in Table - 1. Table shows that there was a wide variation in the texture of these soils and the $\mathrm{pH}$ ranged from slightly acidic (Inceptisol) to slightly alkaline (Vertisol). Alfisol showed almost natural reaction.

The organic carbon ranged from $0.47 \%$ to $0.50 \%$. The $\mathrm{P}$ status of the soils showed marked variation owing probably to the differential $\mathrm{P}$ fertilization in the past.

\section{Correlation coefficient between soil properties and adsorption parameters}

The relevant simple correlation coefficient values are presented in Table - 3. Correlation of Adsorption parameters of Langmuir and Freundlich Isotherms were worked out taking all soil types together with $\mathrm{pH}$, clay, silt + clay, organic carbon, available $\mathrm{P}$ and total $\mathrm{P}$. For the Lamgmuir equation, value of ' $r$ ' indicated that $\mathrm{P}$ adsorption maxima was 
significantly and positively correlated with $\mathrm{pH}\left(\mathrm{r}=0.85^{* *}\right)$, clay $\left(\mathrm{r}=0.96^{* *}\right)$ and silt + clay $(\mathrm{r}=0.94 * *)$. Similar positive correlations were also observed by Saha et al., (1999) between clay and ' $b$ '. The binding energy a significant positive correlationship with organic carbon $\left(\mathrm{r}=0.68^{*}\right)$ only. The result shows that these soil properties influenced $\mathrm{P}$ adsorption strongly for all three soil types. The high and significant positive correlation of silt + clay with $\mathrm{P}$ adsorption maxima implies that a considerable portion of silt along with clay is also active in P adsorption. Das et al., (1983) also found a highly significant positive correlation of some Alfisol of Orissa with their clay content. Singh et al., (1996) found that $\mathrm{P}$ adsorption by Alfisol was closely related with soil clay and organic matter.

Table.1 Physico-chemical properties of soils under study

\begin{tabular}{|c|c|c|c|c|c|c|c|}
\hline \multirow[t]{2}{*}{ Soil } & \multicolumn{3}{|c|}{ Soil Texture } & \multirow[t]{2}{*}{ pH } & \multirow{2}{*}{$\begin{array}{c}\text { Organic } \\
\text { Carbon }\left(\mathrm{g} \mathrm{kg}^{-1}\right)\end{array}$} & \multirow{2}{*}{$\begin{array}{c}\text { Olsen P } \\
\left(\mathrm{kg} \mathrm{ha}^{-1}\right)\end{array}$} & \multirow{2}{*}{$\begin{array}{c}\text { Total P (kg } \\
\left.\text { ha }^{-1}\right)\end{array}$} \\
\hline & Sand $(\%)$ & Silt (\%) & Clay (\%) & & & & \\
\hline \multicolumn{8}{|c|}{ Inceptisol } \\
\hline A & 35 & 26 & 39 & 6.7 & 0.47 & 38.61 & 1777 \\
\hline B & 43 & 27 & 20 & 6.8 & 0.51 & 9.14 & 1237 \\
\hline $\mathrm{C}$ & 45 & 27 & 28 & 6.5 & 0.53 & 15.32 & 1215 \\
\hline $\mathrm{D}$ & 43 & 27 & 30 & 6.4 & 0.44 & 16.16 & 1291 \\
\hline \multicolumn{8}{|c|}{ Alfisol } \\
\hline A & 23 & 29 & 48 & 7.3 & 0.46 & 26.81 & 1411 \\
\hline B & 27 & 39 & 42 & 7.2 & 0.50 & 25.50 & 1366 \\
\hline $\mathrm{C}$ & 22 & 33 & 45 & 7.0 & 0.41 & 23.80 & 1344 \\
\hline $\mathrm{D}$ & 25 & 34 & 41 & 7.2 & 0.49 & 23.74 & 1369 \\
\hline \multicolumn{8}{|c|}{ Vertisol } \\
\hline A & 15 & 29 & 56 & 8.1 & 0.51 & 10.96 & 1559 \\
\hline $\mathrm{B}$ & 21 & 25 & 54 & 8.3 & 0.53 & 32.14 & 1833 \\
\hline $\mathrm{C}$ & 15 & 29 & 56 & 8.0 & 0.51 & 11.83 & 1569 \\
\hline $\mathrm{D}$ & 15 & 30 & 55 & 8.5 & 0.50 & 36.41 & 1852 \\
\hline
\end{tabular}

Table.2 Correlation coefficient between soil properties and adsorption parameters

\begin{tabular}{|l|c|c|c|c|}
\hline \multirow{2}{*}{ Soil properties } & \multicolumn{2}{|c|}{ Langmuir } & \multicolumn{2}{c|}{ Freundlich } \\
\cline { 2 - 5 } & 'b' ' $\mathrm{b}^{*}$ & 'n' & 'k' \\
\hline $\mathrm{pH}$ & $0.85^{* *}$ & 0.41 & -0.38 & $0.75^{*}$ \\
\hline Organic carbon & $0.96^{* *}$ & 0.23 & -0.61 & 0.63 \\
\hline Clay & 0.07 & $0.68^{*}$ & 0.48 & 0.57 \\
\hline Silt+ clay & $0.94^{* *}$ & 0.15 & -0.61 & 0.57 \\
\hline Available P & 0.04 & -0.12 & -0.30 & -0.02 \\
\hline Total P & 0.50 & 0.14 & -0.50 & 0.35 \\
\hline
\end{tabular}

Table.3 Multiple regression coefficients

\begin{tabular}{|l|l|l|l|l|l|l|l|l|}
\hline Isotherms & Adsorption & $\mathbf{p H}$ & Org. carbon & clay & Clay + salt & Av. P & Tot. P & \multirow{2}{*}{$\mathbf{R}^{2}$} \\
\cline { 3 - 8 } & parameters & $\mathbf{B}_{\mathbf{0}}$ & $\mathbf{B}_{\mathbf{1}}$ & $\mathbf{B}_{\mathbf{2}}$ & $\mathbf{B}_{\mathbf{3}}$ & $\mathbf{B}_{\mathbf{4}}$ & $\mathbf{B}_{\mathbf{5}}$ & \\
\hline \multirow{2}{*}{ Langmuir } & 'b' & 18.11 & -15.61 & $8.89^{* *}$ & -7.55 & -1.01 & -0.06 & 0.98 \\
\cline { 2 - 9 } & 'k' & -0.19 & 0.01 & 0.00 & 0.41 & 0.00 & 0.00 & 0.52 \\
\hline Freundlich & 'n' & -1.34 & 0.46 & -0.05 & 8.69 & 0.02 & 0.00 & 0.78 \\
\hline & 'k' & 0.74 & 10.30 & -0.08 & 50.64 & 0.03 & -0.01 & 0.56 \\
\hline
\end{tabular}




\section{Multiple regression coefficients}

Multiple regression analysis(Table 3) was carried out to assess the combined effect of soil $\mathrm{pH}$, organic carbon, clay + silt, available $\mathrm{P}$ and total $\mathrm{P}$ to different adsorption parameters of both Langmuir and Freundlich Adsorption Isotherms. The regression analysis indicated for $98 \%$ of ' $n$ ' and $56 \%$ of the Freundlich ' $\mathrm{K}$ '. However, the regression coefficient for clay was only found to be highly significant indicating that the clay content dominated the $\mathrm{P}$ adsorption of these soils, Jalali and Sharma (1987) also found $80.5 \%$ variation in $\mathrm{P}$ adsorption due to clay and organic matter out of which $73 \%$ was due to clay content. $\mathrm{pH}$ may decrease or increase or have no effect on $\mathrm{P}$ sorption depending upon the experimental conditions (Tomar, 2000).Positive and significant correlation between $\mathrm{P}$ adsorption and clay content have been reported by several workers Teckchand and Tomar, 1992, Murthy et al., 1996; William et al., 1958, Udo and Uzo, 1972 and Khalid et al., 1977.

\section{References}

Black, C. A., 1965. Methods of Soil Analysis. Amer. Soc. of Agro. Inc. Publ. Madison, Wisconsin, USA.

Das, S.K., Rishi, A.K. and Goswami, N.N. 1983. Quality factors of soil phosphorus and utilization of fertilizer phosphorus by barley J. Indian Soc. Soil Sci. 31: 4346

Holford, I.C.R., Chater, M. and Mattingly, G.E.G., 1990. Effect of decalcification on the phosphate sorption characteristics of eight calcareous soil. Australian Journal of Soil Research. 286:919-928

Jackson, M.L., 1978. Soil chemical analysis. Pentice Hall of India Pvt. Ltd. New Delhi

Jalali, V.K., and Sharma P.K. 1987.
Phosphorus adsorption characteristics of some Himalayan soils. Proceeding of national Symposium on Micronutrients in Soils and crops held at PAU Ludhiaana Dec.21-23

Khalid, R. A., Patrick, W.H. and Dalaune, R.D. 1977. Phosphorus sorption characteristics of flooded soils. Soil Sci. Soc. Am. J. 41:305-310.

Khanna, S.S., Tomar, N.K. and Gupta, A.P. 1984. Biochemical Transformation of Ferilizer Phosphorus when Mixed With Organic Matter. J. Indian Soc. Soil Sci. 32, 84.

Murthy, I.Y.L.N., Sastry, T.G., Datta, S.C. Nrayanswamy, G. and Rattan, R.K. 1996. Phosphorus adsorption in relation to soil characteristics of Verisols derived from different plant material. $J$. Indian Soc. Soil Sci. 44:224

Olsen, S.R., and Sommers, L.E. 1982. Method of Soil Analysis Part II, Chemical and Microbial PropertiesAgronomy Monograph, No.9 (II edition)

Piper, C.S., 1976.Soil and plant analysis. Indian rprint.Hans Publication Bombay.

Ryden, J.C., and Cyers, J.K. 1975b. Dsorption and isotopic relationship of phosphate sorbed by soil and hydrous ferric oxide gel. J. Soil Sci. 28: 596-609.

Saha, S., Datta, A and Sanyal, S.K. 1999. Phosphate Sorption- Desorption Characteristics of Some Acidic Soils. J. Indian Soc. Soil Sci. 47(1): 34-39

Singh, K.P., and Sarkar, M.C.1985. Effect of fertilizers and manures on the phosphorus adsorption capacity of acid soils. J. Indian Soc. Sci. 33: 311-312

Singh, R.B., Das, S.K., Sharma, K.L. and Reddy, N.M. 1996. Phosphorus adsorption, desorption and availability in Alfisols of varying agro climatic regions. J. Indian Soc. Soil Sci. 443: 381-386

Stevenson, F.J.1982. Organic matter and 
nutrient availability in non-symbiotic nitrogen fixation and organic matter in the tropics. Symposium paper I. Transcripts of $12^{\text {th }}$ International Congress on Soil, New Delhi, 137-151

Tekchand and Tomar, N.K. 1992. Effect of soil properties on the forms of inorganic phosphate in acid soils. J. Indian Soc. Soil Sci. 40:843

Tekchand and Tomar, N.K. 1993.Effect on soil properties on the transformation of phosphorus in alkaline, calcareous soils. J. Indian Soc. Sci. 46: 56

Tekchand and Tomar, N.K. 1995. Effect of soil properties on the kinetics phosphorus fixation in acids soils. $J$. Indian Soc. Sci. 431: 24-27
Tomar, N.K., 2000. Dynamics of phosphorus in soils. J. Indian Soc. Sci. 489(4): 640673

Udo, E.J. and Uzo, F.O. 1972. Characteristics of phosphorus adsorption by some Nigerian soils. Soil Sci. Soc. Am. Proc. 36:879-883

Vig A.C., Dev, G. and Sinha, M.K. 1978a. Characterization of phosphorus adsorption in soils. J. Indian Soc. Sci. 26: $187-189$

Williams, E.G., Scott, N.M. and Mcdonalds. M.J. 1958. Soil properties and phosphorus sorption. Journal of Science and Food Agriculture 9:551-559

\section{How to cite this article:}

Lalit Kumar Yadav, Rakesh Kumar Bhagat and Gourav Kumar Jatav. 2017. To Study the Relationship between Soil and P Adsorption Parameters. Int.J.Curr.Microbiol.App.Sci. 6(8): 2822-2826. doi: https://doi.org/10.20546/ijcmas.2017.608.336 